Old Dominion University

ODU Digital Commons

\title{
Beyond Mere War: Authority and Legitimacy in the Formation of Latin American States
}

Robert H. Holden

Old Dominion University, rholden@odu.edu

Follow this and additional works at: https://digitalcommons.odu.edu/history_fac_pubs

Part of the Latin American History Commons

\section{Original Publication Citation}

Holden, R. H. (2017). Beyond mere war: Authority and legitimacy in the formation of Latin American states. In L. B. Kaspersen \& J. Strandsbjerg (Eds.), Does War Make States? Critical Investigations of Charles Tilly's Historical Sociology (pp. 243-267). Cambridge University Press. https://doi.org/10.1017/ 9781316493694.010

This Book Chapter is brought to you for free and open access by the History at ODU Digital Commons. It has been accepted for inclusion in History Faculty Publications by an authorized administrator of ODU Digital Commons. For more information, please contact digitalcommons@odu.edu. 


\section{Does War Make States?}

Investigations of Charles Tilly's

Historical Sociology

Edited by

Lars Bo Kaspersen and Jeppe Strandsbjerg 


\title{
9 Beyond Mere War \\ Authority and Legitimacy in the Formation of the Latin American States
}

\author{
Robert H. Holden \\ Old Dominion University
}

\section{Introduction}

When observed against the worldwide panorama of state formation, the states of Latin America compose a group with two salient features. The first is a crisis of order and legitimacy. The second is the exceptionally long duration of that crisis, which began in 1808 with the collapse of the Spanish monarchy. On close inspection, irregularities in the depth, character and timing of the crisis appear; for example, Chile, Costa Rica and Uruguay continue to stand apart for their relatively more peaceful, democratic, stable and law-abiding ways. Still, across Latin America, the high expectations raised in the 1980 s by the nearly uniform shift away from military rule and the tumultuous populisms of previous decades, toward more stable and democratic forms of governance, have largely been disappointed. Lawless violence, impunity and the rule of elected but inept and corrupt governments - some of whom have already summoned back to life the old authoritarian habits - persist almost everywhere.

No one is more aware of the protracted nature of the crisis of order and legitimacy, or laments it more, than Latin Americans themselves. "Our States are sclerotic and hypertrophic, incapable of satisfying the needs of our peoples and of providing the fruits that democracy is obligated to deliver," declared Oscar Arias, the retiring president of Costa Rica at yet another summit meeting of Latin American heads of state in 2010. Mocking the high-level chatter about democracy and development that prevails at such meetings, and criticizing the intelligentsia's fondness for sterile theories of the region's "eternal victimization," Arias pointed out that Latin America had advanced little in recent decades, and in some ways had even fallen behind, particularly in three crucial dimensions of state formation: the construction of reliable institutions, respect for the rule of law and bureaucratic effectiveness. His speech was a short, blunt version of the conclusions about 
the region's "crisis of governability" that the United Nations Development Programme (UNDP) reached in its massive 2004 study of Latin American democracy. ${ }^{1}$

What accounts for Latin America's general failure to govern itself according to the constitutional norms its leaders have habitually proclaimed? No matter how we choose to classify the symptoms of distress whether as problems of order, legitimacy, institutional effectiveness or governability - they all point to some fundamental deficiency in the state formation process, toward the existence of what Guillermo O'Donnell has called a "severe incompleteness of the state" that seems to have become even more prominent since the period of democratic consolidation began in the $1980 \mathrm{~s}^{2}$ Accordingly, few items on the research agenda of the historian of Latin American state formation seem more urgent than the twofold problem of accounting for both the source of the legitimacy-order crisis, and its remarkable persistence.

In pursuit of that goal, the section that follows will both suggest a procedural approach to the problem and identify the distinguishing characteristics of the Latin American state. The next section will offer reasons for rejecting as inapplicable the so-called bellicist theory of state growth as an explanation for those characteristics. The third section will argue for the relevance of two neglected spheres of state making, authority and legitimacy. Finally, I will proffer an alternative explanation for the Latin American state's longtime failure to thrive that emphasizes the centrality of beliefs about authority and legitimacy. ${ }^{3}$

1 Oscar Arias Sánchez, "Que cada palo aguante su vela" (República de Costa Rica, Presidencia de la República, 2010). Arias spoke with some authority. Nearing the end of his second (non-consecutive) term as president, he won the Nobel Peace Prize in 1987 for having piloted Central America out of the region-wide war that engulfed it in the 1980 s, during his first period as president (1986-90). For the UNDP study, see Programa de las Naciones Unidas para el Desarrollo, La democracia en América Latina: Hacia una democracia de ciudadanas y ciudadanos (New York: Programa de las Naciones Unidas para el Desarrollo, 2004). Similar confessions of failure can be found in Cumbres Iberoamericanos de Jefes de Estado y de Gobierno, Declaración de Viña Del Mar, November 7-11, 1996, www.segib.org/documentos.php; and in Organization of American States, Convención Interamericana Contra la Cormupión, March 29, 1996, www.oas.org/Juridico/spanish/Tratados/b- $58 . \mathrm{html}$, in which the signatories agreed to "consider" taking steps aimed at adopting "norms of conduct for the correct, honorable and proper observance of public functions."

2 Guillermo A. O'Donnell, "Polyarchies and the (Un)Rule of Law in Latin America: A Partial Conclusion," in: Juan E. Méndez, Guillermo A. O’Donnell and Paulo Sérgio Pinheiro (eds.), The (Un)Rule of Law and the Underprivileged in Latin America (Notre Dame, IN: University of Notre Dame Press, 1999), p. 314.

3 For another appeal to the relevance of legitimacy in state-making, see the chapter on the Middle East in this volume by Dietrich Jung. 


\section{What Is the Latin American State?}

Turning first to the theoretical literature on state formation, we find at the center of that work the epochal contributions of Charles Tilly, a specialist in the history and sociology of the early modern and modern periods of Europe. Writing toward the end of his career, in the mid1990 s, Tilly described his research program as a "historically embedded search for deep causes operating in variable combinations, circumstances, and sequences with consequently variable outcomes" (emphases added). For good measure, he went on to condemn the "invariant thinking" that had produced so many useless transhistorical models $-\mathrm{a}$ method, he wrote, "doomed to eternal failure." The historical problems to which Tilly had dedicated his career to investigating - collective action, social revolution and state formation - drew him into "big structures, large processes, and huge comparisons," to quote the lighthearted title of one of his books. What Tilly therefore seemed to be promising anyone in search of the "deep causes". of state formation - the theme of this collection - is variability on a vast scale in both process and outcome. ${ }^{4}$ Given both the grandeur and ubiquity of variability, the question is how to handle it. In two short paragraphs, Tilly recommended a threefold procedure. Start with "plausible ontologies - representations of what is to be explained in terms of a given process's boundedness, continuity, plasticity, and complexity." Second, specify the relevant "fields of variation" or the way that the sources, processes, forms and outcomes of, say, state formation, relate to a variety of other phenomena. Finally, a "valid" analysis ought to end up with some "principles of variation" that apply to different aspects of the problem. As always, Tilly did not fail to acknowledge the difficulties and uncertainties awaiting researchers inclined to follow his advice - there was, he warned, "plenty of work to do." 5

Following Tilly, I will begin by offering a brief "plausible ontology" of the states of Latin America. Then, in proceeding to his second step, I will concentrate on two "fields of variation" - first, war making, and second, the interrelated problems of authority and legitimacy. In a nutshell, I intend to reject the first as scarcely relevant, and hold up the second as a cardinal component of any explanation of Latin America's governability crisis. The procedural method is Tilly's, but if there is a "general

${ }^{4}$ Charles Tilly, "To Explain Political Processes," The American fournal of Sociology, vol. 100, no. 6 (May 1995), pp. 1594-1610, here at pp. 1595, 1600, 1602; idem, Big Structures, Large Processes, Huge Comparisons (New York: Russell Sage Foundation, 1984).

5 Tilly, "To Explain Political Processes," pp. 1605-6. 
theory" behind what follows, it would be that of "multiple modernities," as elaborated primarily by S. I. Eisenstadt and Charles Taylor. As the civilization of modernity swept beyond Europe, it created possibilities distinct from those in Europe. The result, according to Eisenstadt: "A great variety of modern or modernizing societies" that shared many features but that also revealed striking differences as a result of those societies' particular responses to modernity and their continued interaction with it. Modernity's spread beyond Europe entailed, therefore, not wholesale adoption, but "the continuous selection, reinterpretation and reformulation" of modernity's norms as well as the emergence of distinctive institutions. ${ }^{6}$ A clear case of such "reformulation," I argue, is the Latin American state. It is true that one can find distinct trajectories of state making within Latin America, as already noted in the first paragraph of this essay, but they took place along a larger path that clearly diverged from, say, the western European or the North Atlantic path, as will be seen below. In its insistence on the continuous reinterpretation and adaptation of modernity's cultural program, Eisenstadt's theory coincides with Tilly's own suppositions about variation.

Let us begin by improving Tilly's definition of the state, which he called "a distinct organization that controls the principal concentrated means of coercion within a well-defined territory, and in some respects exercises priority over all other organizations operating within the same territory."7 This definition only implies an end or purpose that ought to be made explicit, which I would do by adding that the state's end is always to abate disorder by creating a system of laws not subject to any other power. ${ }^{8}$. Tilly refers to this aspect of the state only obliquely ("and in some respects exercises priority over all other organizations"), probably because he was operating in the modern European arena, where it could be taken for granted. As we have

${ }^{6}$ S. N. Eisenstadt, Comparative Civilizations and Multiple Modemities, vols. 1 \& 2 (Leiden: Brill, 2003), 2:520-2. Similarly, Charles Taylor noted that modernity can only be understood in the plural, in terms of the diverse "self-understandings" or multiple "social imaginaries" that have constituted modernity; Charles Taylor, Modern Social Imaginaries (Durham: Duke University Press, 2004), pp. 1-2.

7 Charles Tilly, Coercion, Capital and European States, $A D$ 990-1990 (Oxford: Basil Blackwell, 1990), pp. 130-1.

8 My definition is a compound of F. H. Hinsley, Sovereignty (London: C. A. Watts \& Co., 1966), pp. 16-17, 21; and Alexander Passerin D'Entrevès, The Notion of the State: An Introduction to Political Theory (Oxford: Clarendon Press, 1967), p. 96. We could step back still further and consider Oakeshott's distinction between a state understood as a lordly "managerial apparatus" (universitas) or as a free "association of human beings" (societas), and his argument that both views have been "contingently joined by the choices of human beings in the character of a modern European state"; Michael Oakeshott, On Human Conduct (Oxford: Clarendon Press, 1975), p. 323. 
already seen, however, order is not an end that can be taken for granted in the Latin American state-building context:

At the outset, therefore, we would have to concede that the primary attribute of quite a few Latin American states has been their lack of achievement as states, for in their quest to abate disorder, they have manifestly failed. In most of the Central American countries, as well as generally in Bolivia, Colombia, Ecuador, Peru, Venezuela and periodically almost everywhere else, we see continuing signs of the world's oldest crisis of independence -202 years, as of this writing, and showing little sign of easing. If Tilly's calling was to explain the success of certain states in the North Atlantic world, it has fallen to others to try to explain the historic feebleness and inferiority of their Latin American imitators. Over time, their failure has expressed itself in numerous ways - in the more or less constant agony of reorganization, the fugacious loyalty of a congeries of fighting forces, the indignity of not possessing the legitimacy required for an authoritative system of laws to command widespread obedience.

I have tried elsewhere to explain these qualities, with particular attention to the five states of Central America, by holding up what I called these states' "improvisational character." "Their well-known inclination toward instability, I wanted to point out, was rooted in a commitment to the habitual reassembly of the state apparatus itself, on a pro tempore basis, out of the labor of a mélange of collaborators, including regional caudillos (roughly, warlords or political bosses) and their followers, municipallevel authorities and strongmen and, later, the armed forces or factions of the armed forces. This constant need among state makers to attract and maintain allies made the state's officeholders much more than a mere government, for they were essentially reorganizers of the state itself. Nowhere was that reorganizational task more evident than in the primordial requirement of every new government to attract and hold the loyalty of the fighting forces to which it owed its rise to constitutional office, and the concomitant need to kill off, buy off or otherwise co-opt anyone capable of mobilizing an opposing force. The significance of this fact goes well beyond a simple computation of relative troop strength at the disposition of the contenders. For it was not the capacity or strength of the state's incumbents vis-à-vis its opponents that mattered as much as the certain knowledge among the subjects of the state that the state itself was not the ultimate power holder. In short, real sovereignty was held by

${ }^{9}$ Robert H. Holden, Armies without Nations: Public Violence and State Formation in Central America, 1821-1960 (New York: Oxford University Press, 2004), ch. 1, pp. 25-8; idem, "Constructing the Limits of State Violence in Central America: Towards a New Research Agenda," Journal of Latin American Studies, vol. 28, no. 2 (May 1996). 
whatever fighting forces had won the last battle or could plausibly threaten the incumbents. Chronically improvisational, such states could scarcely expect to apply their legislative dispositions except by violence, owing to the fact that they were not perceived as either the legitimate or even the ultimate source of the power required to enforce compliance. It was therefore frequently expedient for the nominal subjects of these nominal governments to bargain independently with various fighting entities instead of with the government itself. ${ }^{10}$

Over time, the symptoms of improvisationalism changed. Outright warfare among rival caudillos for control of the state had faded in most of Latin America by the late nineteenth century, though in some places such as Central America it continued well into the twentieth century. Rival party militias under the command of their respective caudillos contested the Costa Rican civil war of 1948 , obeying a pattern that also graced the politics of Honduras and Bolivia, among others, into the 1950 s. What persisted almost everywhere, with a diversity of manifestations, were the particularisms of a patrimonial political culture in which expressions of power remained tied, not to institutions of state, but to individual strongmen or their organizations.

A second feature of the "plausible ontology" that Tilly called for follows from the first. Recall that taxation/extraction (Tilly applies the terms interchangeably) was one of the three corners of Tilly's triangular model of interactive state making (the other two being war making and capital accumulation). ${ }^{11}$ But in most of Latin America we have not often seen "states" engaged in an unqualified way in the collection of revenue for state-building purposes. For the most part, state makers have been predatory rent seekers dependent on clientelistic networks to distribute plunder and dispense violence. The last attribute has probably lost some of its validity over the last two or three decades, but it is by no means irrelevant even today; in fact, it is a fair description of political life in Guatemala in 2010, where huge personal fortunes stand to be made by state agents who avoid taxation/extraction and who subvert the state's responsibility for maintaining order. ${ }^{12}$

${ }^{10}$ Holden, Armies without Nations, pp. 25-6.

11 Tilly, Big Structures, p. 141; idem, "War Making and State Making as Organized Crime," in: Peter B. Evans, Dietrich Rueschemeyer and Theda Skocpol (eds.), Bringing the State Back In (Cambridge University Press, 1985), pp. 169-91, here at p. 172.

${ }^{12}$ For many people in Latin America, especially in countries such as Guatemala, El Salvador, and parts of Mexico and Brazil, power over their lives has been routinely exercised for generations by shadowy, composite "governments" of politicians, gangsters, soldiers and wealthy entrepreneurs who pact, divide, compete, make war and realign under conditions of total unaccountability. For Guatemala, Ivan Briscoe magisterially synthesized the evidence in "A Criminal Bargain: The State and Security in 
Grzymala-Busse pointed out the importance of distinguishing between the capture of resources by the state (Tilly's idea) and the capture of resources by state agents. She observed that because predatory regimes "deliberately weaken state institutions," they have the weakest states and they tend to be more personalistic. ${ }^{13}$ Predation and personalism remain well-known features of the patrimonial values underlying Latin American state formation, and highly congruent with the region's equally notorious inconsistency in applying the rule of law.

Finally, the continuity of state incompetence ("fragility" appears to be the favored euphemism at the moment), including the violence that has always seemed to accompany the patrimonial political culture of the region, has to be recognized. A 2007 UN report on the five states of Central America (Costa Rica, El Salvador, Guatemala, Honduras and Nicaragua) described them as places where "violence appears to be endemic" and the rule of law practically nonexistent. Levels of general violence, homicide rates and kidnapping for ransom were among the highest in the world, having actually risen since the regional wars ended there in the early 1990s. State agents, including those charged with maintaining lawful order, routinely collaborate with the non-state perpetrators of criminal violence. ${ }^{14}$ In Brazil, an investigator observed in 2000, "The first and most basic issue in the next decade for government and civil society is to cope with lawless violence." The systematic violation of rights has been "a trademark of Brazilian political history" at least since the end of the empire, in $1889 .{ }^{15}$ In Rio de Janeiro, dealers in illegal drugs since at least 2000 have become a "new type of political actor" by building "mediated links into the state not just to obtain resources but also to gain access to the state power that facilitates their ongoing criminal activities."16 During Argentina's December 2001 wave of looting and vandalism, police and other state agents maintained their reputation

Guatemala," working paper no. 88 (Madrid: Fundación para las Relaciones Internacionales y el Diálogo Exterior, 2009) www.fride.org/publication/658/the-stateand-security-in-guatemala.

13 Anna Grzymala-Busse, "Beyond Clientelism: Incumbent State Capture and State Formation," Comparative Political Studies, vol. 41, no. 4/5 (April/May 2008), pp. 638-73, here at p. 639.

${ }^{14}$ United Nations Office of Drugs and Crime, Crime and Development in Central America: Caught in the Crossfire (New York: United Nations, May 2007), p. 17, passim; Briscoe, "A Criminal Bargain," pp. 10-11.

15 Paulo Sérgio Pinheiro, "Democratic Governance, Violence, and the (Un)Rule of Law," Daedalus, vol. 129, no. 2 (2000), pp. 119-43, here at p. 139.

16 Enrique Desmond Arias, "The Dynamics of Criminal Governance: Networks and Social Order in Rio De Janeiro," Fournal of Latin American Studies, vol. 38, no. 2 (May 2006), pp. 293-325, here at p. 298. 
for lawless violence by collaborating with the looters. ${ }^{17}$ In Mexico in 2009 alone, the police and the army confronted each other more than 65 times, guns drawn and sometimes exchanging gunfire, as the army sought to collar drug smugglers within the ranks of the police, even though high-ranking army officers (along with officials of the federal prosecutor's office) themselves were also found working with drug smugglers. ${ }^{18}$ Latin America's 140,000-plus homicide deaths per year are twice the world's average, making it the most violent region in the world after Sub-Saharan Africa. ${ }^{19}$ Democracy remains a distant prospect. "Power has not been dispersed; corruption persists or has worsened; and politics continues to be characterized by personalistic exchange relationships, lack of accountability, wide executive discretion, and absence of the rule of law." 20

Looking back on the three features of the Latin American state just proposed, it seems clear that quite a few countries qualify as places where the prevailing ethos is "parapolitical," recently defined by a group of scholars as situations in which criminals act like sovereigns, and sovereigns act like criminals in a systematic but clandestine way. Individuals associated with the state - especially those responsible for security and intelligence operations - work closely with criminal elements to subvert formal constitutional procedures, while relying on contraband trade and acting autonomously within the political system for criminal purposes. ${ }^{21}$ In Latin America, this is hardly a new phenomenon; what I have called elsewhere the "parainstitutional" agents of public violence have been (I tried to show) deeply rooted features of Latin America's state formation process. ${ }^{22}$

17 Javier Auyero, "The Political Makings of the 2001 Lootings in Argentina," fournal of Latin American Studies, vol. 38, no. 2 (May 2006), pp. 241-65; Laura Kalmanowiecki, "Origins and Applications of Political Policing in Argentina," Latin American Perspectives, vol. 27, no. 2 (March 2000), pp. 36-56.

18 Julie Watson and Olga R. Rodríguez; "In Northern Mexican [sic], Soldiers Increasingly Suspicious of Often Corrupt Police in Drug War," Associated Press, November 9, 2009; Marc Lacey, "In Mexico, Sorting Out Good Guys From Bad," New York Times, November 2, 2008.

19 Alessandra Heinemann and Dorte Verner, Crime and Violence in Development: A Literature Review of Latin America and the Caribbean (World Bank Policy Research Working Paper no. 4041, 2008), pts. 1, 2, 5.

${ }^{20}$ Judith Teichman, "Merging the Modern and the Traditional: Market Reform in Chile and Argentina," Comparative Politics, vol. 37, no. 1 (October 2004), pp. 23-40, here at p. 23.

21 Robert Cribb, "Introduction: Parapolitics, Shadow Governance and Criminal Sovereignty," in: Eric Wilson (ed.), Government of the Shadows: Parapolitics and Criminal Sovereignty (London; New York: Pluto Press, 2009), p. 8.

22 Holden, Armies without Nations, pp. 14-15 and throughout. 


\section{What Can War Explain about Latin American State Making?}

Turning to Tilly's second task, that of specifying the relevant "fields of variation," I would like to begin by weighing the variable in state formation that Tilly made famous - war. As European states engaged in wars to defeat internal rivals and to repulse or devour external ones, they gradually monopolized war making, a process that required huge outlays of resources and thus forced the states, in varying degrees, to bargain with their subjects or soon-to-be citizens, Tilly wrote. Over time, in return for more and more rights, including those of consent and representation, plus the imposition of certain limits on the state's authority over them, citizens gradually paid more taxes, allowed themselves to be drafted into fighting nationalistic and patriotic wars and accepted the central authority's abridgement of local rule. "Capital-intensive" and "coercion-intensive" states followed distinctive paths in this process of negotiation, but everywhere, "bargaining over the state's extractive claims produced rights, privileges, and protective institutions that had not previously existed." ${ }^{23}$ Considering the centrality of that argument to the theme of this collection, I think it is worth recalling the modesty, even selfdisparagement that accompanied Tilly's presentation of his "war makes states" proposition and its many derivatives and elaborations. "The argument brings with it few illustrations and no evidence worthy of the name," he wrote; and again, the argument is "very, very crudely" stated and "may well be wrong. I certainly provided no evidence here for its correctness." ${ }^{24}$ Others have questioned the validity of Tilly's model even for Europe itself. ${ }^{25}$

For the Latin American case, let us begin with Miguel Centeno's splendid study of the relationship between war making and state making, an explicit attempt to test Tilly's proposition that war makes states. In Latin America generally, Centeno observed, "state power has always been shallow and contested" in contrast to Asian and European states. Why? Hypothesizing, with Tilly, that a history of big international wars makes states rich and powerful and even ties them more firmly to the majority of its inhabitants, Centeno argued that just because Latin

23 Tilly, Coercion, pp. 9-10, 68-9, 94, 100-4. Also see idem, Big Structures, pp. 9-10.

24 Tilly, "War Making and State Making," p. 170; idem, Big Structures, pp. 142, 143.

25 Graeme Gill's finely honed summary of the evidence against Tilly concludes that while war may have stimulated the growth of state bureaucracies and their tax-collection capacities, factors other than war were at least as important, and sometimes war mattered very little; The Nature and Development of the Modern State (New York: Palgrave Macmillan, 2003), pp. 154-8. 
American states so rarely engaged in big international wars, they have remained comparatively weak, underdeveloped and incompetent: "The geopolitical tendency toward peace and the underdevelopment of the state are closely linked." But why didn't the Latin American state fight big international wars? "Because it did not form sophisticated political institutions capable of managing wars. No states, no wars." Thus, on this view, it takes competent states to make big war. But it also takes big wars to make competent states, for international peace "deprived the [Latin American] states of a potentially important impetus for development." The argument is explicitly circular, for it states that the reason states did not go to war was because they were too weak and disorganized to do so. And the reason that they stayed weak is because they did not go to war. Besides making them unfit to fight big wars, the incompetence of these states had another consequence: it made them incapable of preventing internal conflict, and as a result, civil war and political violence became almost routine. ${ }^{26}$ Evidently, then, the appropriate question is, "Why were the Latin American states weak and incompetent to begin with?" for this is the condition that explains why they supposedly avoided big wars in the first place, and presumably why they continued to avoid big wars while confronting serious political violence within their own borders. Centeno acknowledged as much, a point I will return to in due course.

While Centeno excluded the Central American countries from his analysis of Latin America, he nevertheless observed that they represented unspecified "important exceptions" to his arguments. ${ }^{27}$ Now I would like to undertake my own test of Tilly's proposition by focusing on the Central American states, emphasizing three points. First, as I have argued elsewhere, "war" needs to be broadened into "public violence" in order to capture more accurately the reality of this aspect of state formation. The modern association of "war" with organized (and overwhelming) violence between nation-states with clearly defined borders would limit and even distort the reality of violent conflict on the isthmus over the last two centuries. Of course "wars" in the plain sense of the

${ }^{26}$ Miguel Angel Centeno, Blood and Debt: War and the Nation-State in Latin America (University Park: Penn State University Press, 2002), pp. 20-6, 265-9, 271. Both Centeno's characterization of Latin America as a region that has avoided large-scale international war since independence, and his explanation, were challenged by Jorge I. Dominguez, who argued that the Latin American "peace" only began in the late nineteenth century, and was owing to international factors including the maintenance of a South American balance of power. Jorge I. Dominguez, Boundary Disputes in Latin America (Washington DC: United States Institute of Peace, 2003), p. 20, passim.

27 Centeno, Blood and Debt, 1, n.1. 
word did take place but they can best be understood within the larger perspective conveyed by "public violence" - the killing, maiming and destruction that take place within the field of state power, engaging not only agents of the state but their collaborators and rivals - including criminal gangs, death squads, party militias, vigilantes and twentiethcentury guerrilla "armies of national liberation." 28 Second, in comparison to the rest of Latin America, the isthmus has probably endured more public violence than any other country or area of the region. ${ }^{29}$ Third, few episodes of public violence in Central America have been devoid of strong international dimensions, often including the direct participation of forces of various kinds from neighboring isthmian countries (as well as the United States from time to time), so that almost all strife even when contained within the borders of a single country can usually be considered international in scope. As a result, it cannot be said that Central America has been lacking in international violent conflict.

In short, the Central American countries have sustained nearly two centuries of intense state-associated violence - almost all of it with strong international aspects - and yet can still claim to have some of the most feeble and incompetent states in all of Latin America. Even the Cold War period's fusion of internal and external threats associated with communism did little to enhance state capacity, for the build-ups that occurred were almost entirely confined to military and other securityrelated functions, rather than, say, any significant gain in "extractive" capacity or in levels of accountability to a newly empowered citizenry. Moreover, they were paid for by a resource-rich ally, the United States. When the threat of communism faded in the late 1980 s, and the military more or less submitted itself to civilian rule, the state as a whole remained weak and ineffective. Whatever gains to state effectiveness may have been owing to international conflict elsewhere, it sapped state effectiveness in Central America, further impoverishing their inhabitants while whittling away at what little legitimacy might be attributed to the state. In Central America, we see inept states but no lack of internationally oriented conflict. State incompetence cannot therefore be explained by the absence of international conflict in Central America - a place that, as Lindo-Fuentes put it, war had already become a "way of life" within the first two decades of independence. ${ }^{30}$

${ }^{28}$ For more on "public violence" as a concept see Holden, Armies without Nations, pp. 9-24.

29 Holden, Armies without Nations, pp. 28-9.

30 Héctor Lindo-Fuentes, Weak Foundations: The Economy of El Salvador in the Nineteenth Century (Berkeley: University of California Press, 1990), p. 48. 
Costa Rica is the one exceptional Central American state - for its comparative capacity, stability, legitimacy and achievements in extending the benefits of social democracy. These are characteristics that even set it apart from most other countries in Latin America. Like its isthmian neighbors, Costa Rica's public violence has invariably been strongly international in character, involving alliances as well as strife with the fighting forces of other states. On the other hand, by the $1920 \mathrm{~s}$, Costa Rica had allowed its armed forces to shrink to the point that the national military establishment could be abolished after the 1948 civil war with scarcely a word of dissent, and replaced with a national gendarmerie. Tilly's dictum would suggest "no military, so no war, and therefore no state." But this is exactly the opposite of Costa Rica's experience. Having abolished its national military establishment, Costa Rica became a comparatively successful state, so that success could no more be said to be the result of international conflict and militarization than could the failure of the other four countries of Central America. ${ }^{31}$ Costa Rica is a successful state, and the others are failures or nearfailures. Yet all have regularly had to confront internationalized violence, though Costa Rica for most of the last century has carried on without a regular military establishment.

In Central America, as in much of the rest of Latin America, war and the threat of war cannot therefore be said to have exercised a strongly independent influence on the course of state formation except to further debilitate already-decrepit states. They were born weak, unstable, coercive, quasi-legitimate and incompetent, and - with the few exceptions already noted - they stayed that way. The Tillyesque idea that a certain relationship between "war" and "the state" exerted an independent effect on the formation of the state should be discarded, for Latin America at large and the Central American region in particular.

\section{When Is a State or Government "Legitimate"?}

In the conclusion of his book, Centeno left a provocative clue to a very different explanation for state feebleness in Central America and elsewhere in Latin America. He observed that war can only contribute to state making among states that are reasonably well organized to begin with. Europe enjoyed these preconditions for successful state making -and thus war making - but Latin America did not. As a result, Latin

${ }^{31}$ This finding - that war sometimes didn't make viable states, and that viable states could arise without war - parallels Gill's criticism of Tilly for Europe; Gill, The Nature and Development of the Modern State, pp. 154-8. 
American countries were not prepared to fight big wars, so they didn't. War, Centeno concluded, was little more than an "accelerating mechanism for a process that had its origins somewhere else [emphasis added]." But just where is that "somewhere else"? For the deep causes of diverse state-formation processes, the place to go, Centeno asserted, is "the very problem of political authority and order," for states probably cannot come into being "where no authority has previously existed." Centeno divided "authority and order" into two components, both of which Latin America lacked: "organization" and a socio-cultural congruence between states and the communities they sought to dominate. ${ }^{32}$ Ending up by rejecting the Tilly dictum as inapplicable in Latin America, Centeno therefore suggested but did not develop an alternative hypothesis for state incompetence.

The rest of this essay takes over where Centeno left off, by proposing to analyze authority as an alternative "field of variation" that could be helpful in understanding diverse state-formation outcomes. However, in a flagrant departure from the conventional use of the term "authority," I refer, not to the one who holds power (potestas) but rather to the authoritative source (auctoritas) of a norm or moral principle, in this case norms or principles that can be applied to test the legitimacy of a regime or government. My main guide here is the work of the late Alvaro D'Ors, the Spanish jurist for whom the key to understanding human organization of any kind could be found in the fundamental character of the distinction between potestas and auctoritas. Legitimacy (legitimus) derives from law (lex), implying that power exercised under the law is legitimate power. "Law" in this context implies more than mere "legality" (i.e., positive law enunciated by some social collectivity) but a more permanent law, one that does not depend on a social contract but on principles of natural or divine law, as well as the rational requirements of scientific knowledge. Such is the "authority" that confers legitimacy. Yet this authority cannot be effective unless it is socially recognized, perhaps by way of state-established courts of justice, the voice of a widely respected individual, certain institutions independent of the state, or religious authorities. Hence I refer to "legitimating authority" (i.e., an authority according to which legitimacy is rightfully weighed) rather than to the more conventional "legitimate authority" (i.e., a power holder considered to be legitimate).

32 Centeno, Blood and Debt, pp. 106-7, 275-8. Centeno added that war can make states only when "some form of union" emerges between state institutions, on the one hand, and a particular social class, but this condition has been fulfilled numerous times in certain countries without any discernible impact on state competence. 
So, on D'Ors' view, the role of authority is never to exercise power but to speak to power. Authority is always counterposed to power. The role of power is to seek the approval of authority but never to claim it for itself, for to do so would be to exceed its natural limits. And like authority, power too must be "socially recognized," though the most influential factor in the social recognition of power will be whether or not it has received the assent of authority. D'Ors encapsulated his argument about the distinction between authority and power in two now-famous aphorisms: La autoridad es el saber socialmente reconocido y la postestad es, precisamente, el poder socialmente reconocido ("Authority is socially recognized knowledge, and power is precisely socially recognized power"). From which it follows, Pregunta quien puede y responde quien sabe ("He who can, asks; he who knows, answers"). Only those with the sociallyrecognized power to do so can question authority; only those with socially recognized authority can reply. Hence, authority can never execute or block acts that belong to power; it can only endorse or condemn them. Of course, whether power actually enjoys the assent of authority may be uncertain, as can the degree of power's social recognition. In any case, the modifier "legitimate" cannot logically be applied to authority; authority is authority, and it never depends on power. Only power can be legitimate or illegitimate. ${ }^{33}$

If the norm is power's strict separation from authority, the tragic drama of our age, according to D'Ors, has been the state's ascription of authority to itself, a move that entailed replacing legitimacy with mere legality. The state, as the source of positive law, in effect claims to legitimate itself, as did the agents of the state established by the French Revolution. As the nineteenth century wore on, liberal democratic regimes dropped all references to legitimacy except as pure constitutional legality. The trend culminated in Hans Kelsen's famous justification of political power as purely a matter of law, which alone bestows legitimacy. As a result, modern democracies struggle to make a coherent appeal to legitimacy. For example, a particular government is said to be "illegitimate" when it lacks popular support and can only govern by force. But

33 Alvaro D'Ors, Ensayos de teoría política (Pamplona: Ediciones Universidad de Navarra, 1979), pp. 85, 91-2, 112, 151-2; idem, La violencia y el orden (Madrid: Editorial Criterio-Libros, 1998), pt. 2a, cap. 1. An excellent introduction to D'Ors' thought is Frederick D. Wilhelmsen, "The Political Philosophy of Alvaro D'ors," The Political Science Reviewer, vol. 20 (Spring 1991), pp. 144-85. The distinction among power, legitimacy and authority demanded by D'Ors is also asserted by Jean Elshtain, Sovereignty: God, State and Self (New York: Basic Books, 2008), pp. 12-13. For a similar interpretation see Hannah Arendt, "What Was Authority?" in: Carl J. Friedrich (ed.), Authority (Cambridge: Harvard University Press, 1958), pp. 81-112. 
what proportion of the population does it take to make a government illegitimate? German and Italian totalitarian regimes were at one time massively popular; a majority of Germans and Italians never came close to resisting them. But none of us today would qualify either regime as legitimate. The only alternative, it would seem, is to seek legitimacy in the authority of the natural law tradition or in divine law. Indeed, D'Ors asserted, the notion of legitimacy as something greater than law has persisted, and with it the lingering assumption that only a power that complies with that "something" merits obedience. ${ }^{34}$

A more immediate consideration, for the purposes of this essay, is to notice how the failure to properly distinguish authority, legitimacy and power has emptied "legitimacy" of any substantive meaning, even though we cannot seem to let the concept go. In the mid-1970s, "legitimacy" was already "pretty unfashionable" among scholars, wrote Peter $\mathrm{H}$. Smith at the time. He argued that "the cultural determinants of politics" (by which he meant legitimacy) were being overlooked by investigators who erroneously assumed that Latin America must be evolving toward democracy. ${ }^{35}$ By then, scholars of the Latin American state were already displaying a nearly exclusive interest in power and its distribution, in the belief that power alone authorizes and legitimates, or that legitimacy, if it exists at all, is too hard to define and impossible to measure, or that legitimacy discourses are nothing but the cunning dissimulations of powerholders. ${ }^{36}$ Richard Morse stood practically alone among prominent historians of Latin America in conceiving the core

D'Ors, Ensayos de teoria politica, pp. 151-2, 135-46; D'Ors' claim that liberalism can give no convincing account of the source of its authority because modern democratic regimes have in effect swallowed authority is shared by Stephen R. L. Clark, Civil Peace and Sacred Order (Oxford: Clarendon Press, 1989), pp. 82, 92. Cognate arguments can be found in Oliver O'Donovan, The Desire of the Nations: Rediscovering the Roots of Political Theology (Cambridge University Press, 1996), pp. 30-1, 49, 89-90; Carl J. Friedrich, Tradition and Authority (New York: Praeger Publishers, 1972), ch. 8; Jacques Maritain, Man and the State (London: Hollis \& Carter, 1954), pp. 115-20; Bertrand de Jouvenel, Sovereignty: An Inquiry into the Political Good (University of Chicago Press, 1957), pp. 29-33.

35 Peter H. Smith, "Political Legitimacy in Spanish America," in: Richard Graham and Peter H. Smith (eds.), New Approaches to Latin American History (Austin: University of Texas Press, 1974), pp. 225-55, here at pp. 227, 254. "Dominance" and "achievementexpertise" were his proposals for Latin American-type legitimacies.

${ }^{36}$ For examples, see Derek Sayer, "Everyday Forms of State Formation: Some Dissident Remarks on 'Hegemony'," in: Gilbert M. Joseph and Daniel Nugent (eds.), Everyday Forms of State Formation: Revolution and the Negotiation of Rule in Modern Mexico (Durham: Duke University Press, 1994), pp. 367-78, here at p. 375; Alan Knight, "The Modern Mexican State: Theory and Practice," in: Miguel Angel Centeno and Fernando López-Alves (eds.), The Other Mirror: Grand Theory through the Lens of Latin America (Princeton University Press, 2001), pp. 177-218; idem, "Weapons and Arches in the Mexican Revolutionary Landscape," in: Joseph and Nugent, Everyday Forms of 
problem of the region's political history to have been the search for the legitimization of power. ${ }^{37}$ Occasionally, the fog dissipated enough to suggest once again that something about legitimacy seemed important even if we could not quite put our finger on it. A contemporary example is the UNDP's above-cited 2004 study, "Democracy in Latin America," whose authors argued that Latin Americans had to solve their governability crisis by trying to "build a new legitimacy for the State." The study went on to mention "legitimacy" 22 times over the course of its 288 pages but without once either probing its meaning or discussing the conditions that might give rise to the construction of a "new legitimacy." 38

About midway between Smith's vain attempt to revive the study of legitimacy and the UNDP project, the Brazilian Francisco C. Weffort observed that the entire half-century since the 1930 s had constituted "a crisis of legitimacy" in Latin America. In a poignant and evidently personal reminiscence, Weffort wrote that one had to have lived through that crisis in order to know precisely just how truly it was a crisis of legitimacy, to have shared the general intuition that some fundamental deficiency was ravaging the state, or society, or both at once. "Throughout that period it was (and remains) a characteristic feature of the Latin American mind to know that things were (and indeed remain) 'mistaken,' whatever the place and whatever the reasons for the 'mistake'." Weffort identified the effects of the "mistake" in terms much like the characteristics I earlier associated with the "improvisational state": to Weffort, it was "a chronic instability apparent in the continual threats of coups d'état and in political phenomena such as populism and military interventions. $" 39$

In Weffort's account, "legitimacy" seems to be what that state would have acquired had some fundamental, yet unnamed and rather mysterious defect or "mistake" been corrected. "Something" was out of place, or missing entirely, or its nature perverted. The result was Weffort's "chronic instability," or my "crisis of order and legitimacy," or O'Donnell's "severe incompleteness of the state."

State Formation: Revolution and the Negotiation of Rule in Modern Mexico (Durham: Duke University Press, 1994), pp. 24-66, here at pp. 42-3, 60-2; Florencia Mallon, "Reflections on the Ruins: Everyday Forms of State Formation in Nineteenth-Century Mexico," in: Joseph and Nugent, Everyday Forms of State Formation, pp. 69-106, here at pp. 70-1.

37 Richard M. Morse, New World Soundings: Culture and Ideology in the Americas (Baltimore: Johns Hopkins University Press, 1989), p. 127.

38 United Nations Development Programme, Democracy in Latin America: Towards a Citizens' Democracy (New York: United Nations Development Programme, 2005).

${ }^{39}$ Francisco C. Weffort, "The Dilemmas of Political Legitimacy," CEPAL Revievo, no. 35 (August 1988), pp. 127-42, here at p. 132. 
That "something," that curious omission or deficiency, I propose, is precisely a way of gauging legitimacy that descends from a socially recognized principle of authority, or even from some divergent methods and principles of authority that nevertheless overlap in a complementary way, defusing the potential for conflict among them. When understood as a quality that depends on authority, the concept of legitimacy can be cured of its vaguely intuitive status and acquire the analytical strength it is supposed to possess. To affirm or contest the legitimacy of a given regime or administration is to deploy some norm or cluster of norms dictated by a particular authority. To understand the source of consensus or conflict driven by rival claims of legitimacy, it is not enough to know that one band contests the legitimacy or "right to rule" of a regime, and another one defends it. We need to go further, and try to identify the nature of the authority that each band has chosen as the source of the norms or principles that guides its judgment of the regime's legitimacy. In weighing the legitimacy of a regime, in other words, we find that people believe in one authority or another, and it is precisely the failure to find a way of harmonizing that diversity of beliefs in one or another authority that accounts, in large part, for Latin America's interminable "crisis of legitimacy." To repeat: Authority, on this view, cannot itself be either legitimate or illegitimate, nor can it ever exercise power itself. What authority does require is social recognition, and it is precisely the absence of a more or less unitary, socially recognized principle of authority that distinguishes the Latin American state formation process.

To frame the problem in these terms is to opt for a mode of explanation that grants priority (as Smith sought to do) to the realm of culture in state formation, over against the prevailing preferences for materialist, institutionalist, rational-choice and power-based modes. None of the latter, as Rae argued, can excavate the deep sources of state formation. To understand just why people choose the "interests" that dominate such explanations requires an investigation of the moral content of their choices. ${ }^{40}$ In a similar vein, Lehman identified culture as the primary site for the study of "political legitimations," which he argued (following Berger and Luckmann) are always constituted by values (rules of the game) that in turn require the enunciation of some core moral principles. Partisans and powerholders alike apply moral imperatives - the first, to accuse or acclaim the powerholders; the second, to justify their own power. ${ }^{41}$

${ }^{40}$ Heather Rae, State Identities and the Homogenisation of Peoples (Cambridge University Press, 2002), pp. 24-44, 304-305. The primary field of variation in this study was the definition of insider-outsider boundaries for determining the membership of a polity.

41 Edward W. Lehman, The Viable Polity (Philadelphia: Temple University Press, 1992), pp. 141-2. 
And so we ask, which authority principles were at play in a given society, at a given time? How were they deployed to test the legitimacy of a particular political program, regime or government? How did contention over the rightful sources or principles of authority shape the four most obvious and persistent symptoms of state incompetence: corruption on an Olympian scale, intolerably high levels of public violence and disorder, widespread indifference to the rule of law and political instability?

\section{The Search for Authority in Latin American State Making}

If an enfeeblement of traditional understandings of authority swept the West, as D'Ors averred, the cultural and political codes available to their assailants, their defenders and other actors varied immensely as between, say, Britain and the United States, on the one hand, and New Spain or Spain itself. In this way, following Eisenstadt, the same general movement could yield distinctive outcomes in particular places. If authority was somehow reconstructed or refounded in a non-traditional guise in the first group of countries, in much of Latin America the process of reconstructing authority that should have begun after 1808 remains unfinished. In showing how this might have happened, I would like to outline the ways in which political authority had been understood before the crisis of 1808 , how it had already been challenged well before 1808 by the monarchy itself, and how these conflicting interpretations were then seized on, further reinterpreted and applied in competitive ways in the post-independence republican context.

Basically, the peoples of the new republics divided over three different conceptions of legitimating authority. The first was the traditional, medieval belief ("translation" theory) that authority originates naturally or by divine ordination in the body politic, which freely decides to endow the power to govern upon whomever it regards as the most qualified person or group. The ruler thus holds power by a free act of the people, who can in turn take away that power if it is misused, and transfer it to some more qualified ruler. In translation theory, the consent of the political community is the defining act. Monarchs with absolutist pretensions gradually defined a deviant "designation theory" under which the body politic acts, not freely, but under Providential direction, to designate the ruler whose distinction as a leader is so evident that he must have been divinely chosen for leadership. Here, the political community is duty-bound to make an irrevocable designation. The third approach was the protodemocratic ideology ("liberalism") of the Age of Revolution, into which the Hispanic republics were born. Liberal ideology clearly owed a good 
deal to translation theory, but it also challenged that theory by rejecting the divine-law basis of authority by absolutizing the will of the majority (Rousseau) or the state (Hobbes), and its disregard of the traditionally conceived ends of state power - namely, the protection of the common good. To the liberals, the state was not defined according to any divinely ordered natural "end" but by history, which is to say, by purely human goals and desires. ${ }^{42}$

An underlying clash of "translation," "designation" and "liberal" conceptions of legitimate political authority not only shaped political conflict in Latin America but kept it going, fueled in part by the fact that it followed the destruction of a manifestly incompetent and corrupt monarchy that had defined its authority in terms of a divine-right "designation" theory. Liberals drew on aspects of both translation and designation theories of authority to legitimate their rule. Some conservatives, horrified by the specter of democracy, resorted to the "designation" thesis to defend divine-right monarchy. Liberals eventually did likewise, but now to defend a quasi-absolutist, authoritarian state governed by liberal principles eventually corrupted by utilitarianism, positivism and social Darwinism. Many others - perhaps the most authentically "traditional" elements of society - upheld the "translation" view, along with its distinctive teleology and natural- or divine-law premises.

Three contemporary historians have grappled with the implications of these understandings for nineteenth-century politics in Latin America. O. Carlos Stoetzer documented a heterodox argument in favor of a widespread "translationist" understanding of authority in Hispanic America that, he further claimed, was deployed to justify the rebellion against the Bourbon monarchy. Stoetzer made much of the clash between the designationist outlook of the late Bourbons and the translationist premises of the Spanish Americans, but he confined his analysis strictly to the independence wars. Austen Ivereigh distinguished an "ecumenical" liberalism (strongly translationist) from a "monistic" (more designationist, and thus absolutistic) liberalism. Ivereigh, unlike Stoetzer, recognized that pre-independence assumptions about authority remained in play for some decades after independence, but omitted

${ }^{42}$ Heinrich A. Rommen, The State in Catholic Thought: A Treatise in Political Philosophy (New York: Greenwood Press, 1969 [1945]), pp. 235, 430-3, 443-50, 454-6, 459, 460-4, 469-73. Similarly, conflict over opposing notions of auctoritas - an "ascending" theory that located authority in the people, and a "descending" notion that associated it with a supreme being - was the central theme of Walter Ullmann, A History of Political Thought; the Middle Ages (Baltimore: Penguin Books, 1965). Ullmann further argued that these distinctions persisted into modernity at pp. 7 and 229-30. 
any speculation about how they might have persisted over the long term, and limited his analysis to church-state matters. In a series of works, our third historian, François-Xavier Guerra, not only tracked (like Stoetzer) the impact of distinctive beliefs about authority from the late Bourbon period through the independence wars but went on to document their presence well into the nineteenth century. Guerra also proposed that the conflicts over the nature of the appropriate legitimating authority that animated the independence movement and the politics of the nineteenth century persisted throughout the twentieth century as well. A liberal view of the nation as a voluntary association of equal individuals (among whom sovereignty collectively resided) never ceased to clash with a more traditional understanding of authority that descended from translation theory, in which sovereignty rested in a mosaic of concrete social and geographical corporate entities rather than individual persons. On the second view, legitimacy is conveyed by means of pacts and the enunciation of special privileges, rights and duties associated with the group. Pactismo, or the habit of governing through special arrangements with distinctive groups, in effect lived on to disrupt the liberal project. ${ }^{43}$

One result was the consolidation of personalistic and patrimonial institutions. In the absence of a consensus on the source of authority, the right to rule was increasingly evaluated in highly personalistic terms. Hence caudillismo, patrimonialism, patron-clientage - animated and reshaped after independence under the influence of modernity. Today they remain symptomatic expressions of the absence of a socially recognized moral authority capable of providing the criteria necessary for weighing legitimacy. Thus, the tendency toward crisis, violent disorder

43

O. Carlos Stoetzer, The Scholastic Roots of the Spanish American Revolution (New York: Fordham University Press, 1979); Austen Ivereigh, "Introduction: The Politics of Religion in an Age of Revival," in: Austen Ivereigh (ed.), The Politics of Religion in an Age of Revival: Studies in Nineteenth-Century Europe and Latin America (London: Institute of Latin American Studies, 2000), pp. 1-21, here at pp. 13-15; François Xavier Guerra, "De la política antigua a la política moderna: La revolución de la soberania," in: François Xavier Guerra and Annick Lempérière (eds.), Los espacios públicos en Iberoamérica: Ambigüedades y problemas, siglos XVIII-XIX (Mexico City: Fondo de Cultura Económica, 1998), pp. 109-39, here at pp. 135, 139; idem, Modernidad e independencias: Ensayos sobre las revoluciones hispánicas (Madrid: Editorial MAPFRE, 1992), pp. 51-3, 72-9; idem, "The Spanish-American Tradition of Representation and Its European Roots," Fournal of Latin American Studies, vol. 26, no. 1 (February 1994), pp. 1-35, here at pp. 34-5. See a comparative treatment of the principle of consent in the independence movements of Latin America and the United States by José Carlos Chiaramonte, "The Principle of Consent in Latin and Anglo-American Independence," fournal of Latin American Studies, vol. 36, no. 3 (August 2004), pp. 563-86, here at pp. 577-82. 
and indifference to the rule of law. The authority-centered nature of the crisis also clarifies one of the most glaring features of Latin American political conflict: the ubiquity and persistence of a discourse that demonizes and violently condemns the political enemy while associating him with imminent catastrophe. Precisely because the underlying disagreement concerned the appropriate source of moral authority, there was no place for a political enemy but in jail, exile or a coffin. If mere interests were at stake, a rational choice would have dictated compromise. But in a moral battle, especially one over the identity of authority competent to judge legitimacy, compromise is rarely an option.

Disagreements over basic beliefs about the source of the authority capable of endowing legitimacy seeded and sustained a long-term crisis of legitimacy in Latin America. The range and diversity of such beliefs, as well as their contradictory character and thus their potential for conflict, exceeded the limits of the threefold taxonomy of authority that prevailed in the early decades of independence. Their range and diversity cannot be adequately documented within the scope of a single essay. A few examples will have to suffice to illustrate the endurance and ubiquity of, first, a crisis of legitimacy; second, allusions (usually indirectly or implicitly, and perhaps not even consciously) to diverse authorities in order to justify contradictory legitimacy norms; and third, the demonization and violent condemnation of an enemy associated with imminent catastrophe. All three characteristics are eventually synthesized in a rhetoric of "national salvation" - a phrase that turns up repeatedly in the political history of Latin America.

Such discourses were frequently directed against members of an opposing faction of the same party or political band. The Mexican Gen. Porfirio Díaz' "Plan de la Noria" (November 1871) can be taken as a convenient example. In justifying his revolt against the just-elected government of Benito Juárez, a fellow liberal whose administration Díaz himself had honorably served, Díaz referred to the liberalcontrolled National Congress as "a chamber of courtesans" and "a cataclysm of perversion and immorality"; he accused the Juárez administration of having forgotten "the laws and practices of Christian civilization" and of turning the republic into "an immoral and corrupt farce." Diaz's "Plan" concluded: "Let us fight, then, for the cause of the people and the people will be the sole owner of its triumph." $\mathrm{He}$ pledged "the observance of the constitution" and asserted "that no citizen should impose himself and perpetuate himself in the exercise of power, and this will be the last revolution." Of course, Díaz would go on to violate, more spectacularly than any president in Mexican 
history, the very promises at the heart of his revolt. ${ }^{44}$ But note how he appealed to traditional values and Christian virtues - transcendent authority - in justifying the overthrow of rulers invariably characterized as "tyrants" - a move specifically authorized by the medieval and early modern "translation" theorists.

In 1932, another caudillo, Augusto Sandino, appealed to transcendent authority when he called for Nicaragua's freedom from occupation of the U.S. Marines - a freedom attainable "only by bullets, and at the cost of our own blood, we have said, and that nest of political scoundrels who are fighting each other to take over the whip of the invader will be annihilated by their own guilt in a not too distant future."45 The guerrilla leader's authority for his challenge to the legitimacy of the Nicaraguan state emerged from a self-concocted synthesis of traditional Christianity, magic and paganism. Sandino saw himself as the divinely chosen "warring messiah-prophet" of the imminent redemption of the entire planet, not just Nicaragua. ${ }^{46}$

Three decades later, Sandino's Marxist epigones organized the Frente Sandinista de Liberación Nacional to forcefully remove another tyrannical government. Like Sandino, they claimed exclusive leadership of a redemptive millenarian movement whose quest for a legitimate government originated in their belief in semi-mystical authority. The Sandinistas, as they styled themselves, called their authority "scientific," for it was "history" that justified their challenge to a regime they regarded as illegitimate. Professing faith in the "historical character of the proletariat as the most revolutionary and fundamental class for the maximum development of our liberation process," they identified themselves as the historically denominated "vanguard" and thus the sole legitimate organizer of the proletariat in both its violent conquest of power and its subsequent administration of power. ${ }^{47}$ Unlike Sandino's, their movement triumphed, with the collapse of the dictatorship of Anastasio Somoza Debayle in 1979.

${ }^{44}$ For more examples of the intensely moralistic and violent tone of political rivalry and an extended analysis of political demonization, see Holden, Armies without Nations, pp. 31-3.

45 Augusto César Sandino, Pensamiento político (Caracas: Biblioteca Ayacucho, 1988), p. 445 .

46 Marco Aurelio Navarro-Génie, Augusto "César" Sandino: Messiah of Light and Truth (Syracuse University Press, 2002), pp. 92, 142, 146-57.

47 Frente Sandinista de Liberación Nacional, "Plataforma general político-militar del FSLN para el triunfo de la revolución popular sandinista," in: Dennis Gilbert and David Block (eds.), Sandinistas: Key Documents/Documentos Claves (Ithaca: Latin American Studies Program, Cornell University, 1977). 
In his attempt to lead a socialist revolution from the elective office of the presidency of Chile, Salvador Allende likewise identified his ultimate authority as "history," and the proletariat as its instrument - a discovery he attributed to a synthesis of freemasonry and "the humanism of all ages and particularly ... Marxist humanism." Just as "history" led first Russia and then China to blaze the trail toward socialism, in 1970 "once again, history has permitted a break with the past" in Chile. It was to the authority of history, as revealed by his Marxist-humanist-Masonic ideology, that Allende appealed in justifying the legitimacy of the regime he sought to build in the name of the proletariat: "a democratic, national, revolutionary and popular Government which will open the road to socialism" and to the creation of a "new man" in a "classless society." 48 In 1973, the legitimacy of Allende's government would in turn be challenged by the country's armed forces. In removing what they called "an illegitimate, immoral government" from power, Chile's military leaders appealed to the constitution and the country's laws. They acted, they said, "before God and history," out of a "moral duty" imposed on them by the majority of the population. Two years later, Gen. Augusto Pinochet, the leader of the coup and now the unelected president of Chile, elaborated on the contradictory sources of authority at play in the crisis of 1970-73: "The existence and propagation of Leninism-Marxism in the world today represents the destruction of the basic moral foundations from which the Western and Christian civilizations derive. ... The world today faces an unprecedented form of war" between Christianity and communism. "I devotedly implore Our Holy Lord," Pinochet concluded, to keep Chile's "flame of liberty" from burning out. ${ }^{49}$

Finally, contemporary Latin American political life forces us to consider yet another kind of belief about the source of legitimating authority that has been seen throughout the post-independence history of the region. Where an office of state is understood to be what I described above as an opportunity to distribute plunder and to dispense violence in order to protect plunder rights, there is no interest in achieving anything "for" the state, for to occupy any given office of state is simply to possess an instrument for personal enrichment. The state's grand purpose is still the abatement of disorder through lawgiving and

48 Régis Debray, The Chilean Revolution: Conversations with Allende (New York: Pantheon Books, 1971), pp. 65, 115, 117, 119, 170, 174.

49 Government Junta of the Armed Forces and Carabineros of Chile, "Order of the Day Number 5," in: Brian Loveman and Thomas M. Davies Jr. (eds.), The Politics of Antipolitics (Lincoln: University of Nebraska Press, 1978), pp. 198-9; Augusto Pinochet, "Speech," in: Loveman and Davies Jr., The Politics of Antipolitics, pp. 204, 205,207 . 
coercion, but only insofar as disorder interferes with the aim of selfenrichment. I call it the "entrepreneurial state." Nothing, therefore, about this kind of "modern" state can be explained by Tilly's theory of state expansion, with its neat Weberian assumptions about war making, taxation, bargaining and citizenship. Still, the contemporary Guatemalan state, say, is a modern state, and like every other human artefact, it is the product of ideas about what it ought to be for, or what makes it "legitimate," a status that in turn seeks justification in the name of some kind of authority. To those who have accommodated themselves to the entrepreneurial state, a legitimate state is one that affords office holders and their dependents the freedom to function as entrepreneurs. ${ }^{50}$ The "authorizing" principle of this concept of legitimacy might be moral nihilism, in which values themselves are thought to be arbitrary and justice is therefore a fiction. This principle competes with, but frequently defeats, more traditional, justice-oriented theories of legitimacy put forward in countries such as Guatemala by some political parties, non-governmental organizations, social movements, and religious authorities as well as individuals whose notion of citizenship presumes a different sort of authority principle (perhaps one of those mentioned above) and thus a different standard of legitimacy.

In Latin America, a dynamic diversity of rival moral authorities, and hence a diversity of legitimacies, established the basic conditions for the rise of weak and inefficient states, endless violence and indifference to the rule of law. I identified three main alternative authorities (those linked to liberalism and to translation and designation theory) that first emerged during the period of the independence movements, but it is the very inventiveness of the ongoing search for authorities (as the examples just given reveal) that merits attention at the moment. New or reformed state institutions can achieve little in the absence of a socially-recognized authority - one derived from an axiology conceived variously as secular or supernatural, a composite of the two, or as stemming from the natural law tradition - that is capable of bestowing legitimacy on a state, regime or government. Without such recognition, state institutions are in no position to derive any long-term strength from warfare in any of its guises. War is a feature of Latin American political life that accelerated, not the formation of successful states, as Tilly argued for Europe, but rather state deformation and failure. The fatal impairment of the Tilly thesis is its reification of the state and the corollary of a behavioristic determinism ("wars make 
states") entailed by reification. This essay has documented the sterility of that approach in the Latin American context. Collective entities like states are constituted by individual persons and apart from the acts of persons, they have no independent reality. ${ }^{51}$ This is the principle I have tried to deploy in showing how personal commitments to a diversity of comprehensive beliefs about the sources of moral authority can explain state instability and incompetence more satisfactorily than the Tilly thesis.

51 See the discussion of Paul Ricoeur's reasoning in opposition to a Hegelian-style hypostasis of the state and similar entities in Robert Piercey, The Uses of the Past from Heidegger to Rorty: Doing Philosophy Historically (Cambridge University Press, 2009), pp. 183-6. 